Article

\title{
Air of Uncertainty from Pollution Profiteers: Status of Ambient Air Quality of Sawmill Industry in Ilorin Metropolis, Kwara State, Nigeria
}

\author{
Olalekan Morufu Raimi 1,*(D), Timothy Kayode Samson ${ }^{2}$, Ajayi Bankole Sunday ${ }^{3}$, Adio Zulkarnaini Olalekan ${ }^{3}$, \\ Odipe Oluwaseun Emmanuel ${ }^{4}$, Ogunleye Temitope Jide ${ }^{3}$
}

How to cite this paper: Raimi, $\mathrm{O}$.

M., Samson, T. K., Sunday, A. B., Olalekan, A. Z., Emmanuel, O. O., \& Jide, O. T. (2021). Air of Uncertainty from Pollution Profiteers: Status of Ambient Air Quality of Sawmill Industry in Ilorin Metropolis, Kwara State, Nigeria. Research Journal of Ecology and Environmental Sciences, 1(1), 17-38. Retrieved from https://www.scipublications.com/journal/index.php/rjees/article/view/60

Received: June 22, 2021

Accepted: July 29, 2021

Published: July 30, 2021

Copyright: (c) 2021 by the authors. Submitted for possible open access publication under the terms and conditions of the Creative Commons Attribution (CC BY) license (http://creativecommons.org/licenses /by/4.0/).

\author{
${ }^{1}$ Department of Community Medicine, Environmental Health Unit, Faculty of Clinical Sciences, Niger Delta \\ University, Wilberforce Island, Bayelsa State, Nigeria. \\ 2 Statistics Programme, College of Agriculture, Engineering and Science, Bowen University, Iwo, Nigeria. \\ ${ }^{3}$ Department of Environmental Health Science, Kwara State University, Malete, Kwara State, Nigeria. \\ ${ }^{4}$ Department of Environmental and Occupational Health, School of Public Health, University of Medical Sci- \\ ences, Ondo State, Nigeria. \\ *Correspondence: morufuolalekan.raimi@gmail.com
}

\begin{abstract}
We can't stop breathing, but we can do something about the quality of air that we breathe. Clean fresh air is indispensable ingredient for a good life quality. Individuals poses the right towards expecting that the breathed air will not harm people. Thus, fighting air pollution will not only improve health outcomes, productivity, and well-being, it's also essential toward reducing the emissions of greenhouse gas as well as fighting climate change. For examples, a third of the global population is at risk from unhealthy of ambient air pollutants concentrations, with the loss of approximately 6.4 million healthy-life-years attributed specifically to chronic exposure to ambient particulate matter. Expert panels have consistently rated air pollution as a greater health hazard than water pollution. Pollution of air is the leading source of unexplained and undiagnosed diseases, besides have remained associated with a variety of serious human health risks, and in fact, a threshold has not been established under which these pollutants exert no adverse effects. This study evaluates ambient air quality at major sawmill sites in Ilorin Metropolis, Kwara State, Nigeria. "Measurements of Air pollution were accurately carried out using direct reading, automatic in situ gas monitors; Hand held mobile multi-gas monitor with model AS8900 [Combustible (LEL), and Oxygen $\left(\mathrm{O}_{2}\right)$ ], BLATN with model BR - Smart Series air quality monitor (PM10, Formaldehyde) and air quality multimeter with model B SIDE EET100 (Dust (PM2.5), VOC, Temperature and Relative Humidity)". The outcomes disclosed among others, the average concentrations of $\mathrm{CO}, \mathrm{O}_{2}$ as well as other measured parameters for instance formaldehyde ( $\mathrm{HcHo}$ ) etc., they are also consistently low as well as within acceptable range in terms of National as well as Global monitoring standards for air quality indices. However, there are few exceptions for instance the average volatile organic compounds (VOCs) concentrations, PM2.5, PM10 as well as Combustible (LEL) respectively, which are higher when compared to National and Global standards. This high figure is due to pollutant amount existing in the sawmills air environment resulting from input of influents from activities of the sawmill. However, as a result, air pollution in the city of Ilorin is found to be increasingly polluted and are of major health concern because of their synergistic action. Due to the high evidences and values, it can lead to a remarkable rise in over-all figure of hospital visits/ patients' admissions with acute respiratory illnesses as soon as air pollutants level remained high. Hence, there is the need for an aggressive control of ambient air pollution.
\end{abstract}

Keywords: Pollution profiteers, Regulatory decisions, SARS-CoV-2 infection, Polluters paradise, Heightened mortality risk, Hazardous air pollutants, Cancer alley, Sawmills, Nigeria. 


\section{Introduction}

According to the World Health Organization (WHO), above four (4) million individuals die prematurely from outdoor air pollution yearly. The chief culprits are the fine particles with a diameter of 2.5 micrometres or less ( $\left.\mathrm{PM}_{2.5}\right)$. These can enter the lungs, heart as well as bloodstream, where they cause diseases and cancers. Evidence is mounting of geographical differences in health responses to air pollution. For example, even though the associated death tolls are high in emerging countries, industrializing cities are heavily polluted and more individuals live there, the risk is higher for city dwellers, especially around the sawmill in developing countries like Nigeria are greater. Nigerians are more likely to die from heart disease as well as from acute respiratory attacks than are people in developed countries, when exposed to similar levels of air pollution. Mixtures of air pollutants might also remain more detrimental than their constituents in isolation. For instance, a combination of indoor as well as outdoor air pollution, including tobacco smoke may well be accountable for 2-3 times the number of global premature deaths than the WHO current estimates $[1,2,3,4]$. Limited health effects studies on air pollution consider these discrepancies as well as the lethal short-term health effects of exposure to air pollution are properly documented $[5,6,2,4,7,8,3,9,1,10]$. Certainly, ambient air pollution is recognised or assumed to cause or worsen conditions associated with SARS-CoV2 infection, including cardiorespiratory disease, respiratory disease, obesity, and type 2 diabetes $[11,12,13,14,15,16,17,18]$. So, it is plausible that air pollution exposures could also be risk factors for not only SARS-CoV-2 infection but also worse disease severity and heightened mortality risk. Air pollution, especially particulate matter (PM), poses public health problems due to its toxicity and the widespread human exposure to this pollutant. $\mathrm{PM}$, including inhalable particles through aerodynamic diameter of less than or equivalent to $10 \mu \mathrm{m}\left(\mathrm{PM}_{10}\right)$ and fine particles through an aerodynamic diameter equivalent to or less than $2.5 \mu \mathrm{m}\left(\mathrm{PM}_{2.5}\right)$, are emitted by combustion sources or are formed by transformation of atmospheric chemistry. Given health effects evidence, mean daily as well as yearly concentrations of $\mathrm{PM}_{10}$ and $\mathrm{PM}_{2.5}$ standard are controlled in harmony through quality air guidelines and in major countries [20]. All over the world, both developed and developing countries, the health risk of urban dwellers due to particulate matter are well documented $[19,2,1]$. To assess the health risks accompanying air pollution in developing countries like Nigeria, decision makers are frequently forced toward extrapolating research results in the industrialized countries. Nevertheless, these extrapolations are considered inappropriate and unsatisfactory, given two reasons. Firstly, it is not specific that the association amongst pollution as well as health at comparatively low pollution levels in technologically advanced countries applies toward the extremely high pollution levels found in emerging countries. For example, particulate matter levels are habitually three to four times higher in emerging countries than in technologically advanced countries. Secondly, individuals in emerging countries like Nigeria die earlier and for reasons other than those in industrialized countries, suggesting that extrapolating the effects of air pollution on mortality can be particularly misleading. Schematically, in an increasingly complex industrial society, increasing attention is being paid to technological risks replacing natural hazards as the greatest environmental threat to human life and property. Because economic development is crucial to urban development and growth, economic development has not only brought growth and prosperity, but ultimately economic decline and environmental problems have also affected the regions. Rapid urbanization and industrialization have increased the vulnerability of individuals to various man-made dangers. For most people, the real threat is experienced indirectly. However, a significant number of people are directly confronted with an unhealthy environment simply because of their 
geographical location, living in an area where the real hazards occur. This is the case with residents of the major saw mills in Ilorin, Kwara State, Nigeria.

Within the major sawmills, the proximity of sawmills industry and housing has created a certain amount of controversy about the environmental quality. Residents' right to enjoy the benefits of clean air is limited by the activities of the timber industry. As a result, concerns are raised about the impact of pollution on health. At least a quarter of the global population is unprotected to the risk of air pollution [20], and the loss of nearly 6.4 million years of a healthy life is associated with chronic exposure to ambient particulate matter [20, 2, 21]. Expert panels for the U.S. Environmental Protection Agency, United Nations, and other agencies have consistently cited air pollution as a greater health hazard than water pollution. Both particulate matter $(\mathrm{PM})$ as well as ozone $\left(\mathrm{O}_{3}\right)$ are associated with a number of deleterious effects on human health, and in fact there is no threshold that has been established under which these pollutants exert no adverse effects [22, 20,23]. What we do not know is the difference in the amount of air pollutants concentrations within sawmill environment. Do the levels of air pollution vary significantly within sawmill environment and, if so, is there a pattern to such variability?

Pollution has become one of the major threats to global health and existential challenges of the $21^{\text {st }}$ century and $4^{\text {th }}$ industrial revolution. Much like earth changing climate, ocean acidification, biodiversity loss, desertification, as well as global depletion of the clean water supply, pollution compromises the Earth's sustainability support systems as well as threatens the on-going existence of human societies and its association [24, 2, 21, $25,7,26,27]$. The effects of air pollution on health will affect many communities in the coming years and endanger the lives and wellbeing of billions of people at increased risk. Pollution, particularly triggered through industrial emissions, car exhausts, as well as toxic chemicals, has increased dramatically in the past $[28,9,1,29,30,31,77,78,79,80$, 81]. 500 years, and are considered the largest increase in emerging countries today. Yet despite its great and rapid magnitude growth, industrial, vehicular, as well as chemical pollution in emerging countries has remained largely ignored on global development as well as international health operations, and programmes for controlling pollution have received few attentions or contributions from either philanthropic donors or global agencies abroad. Pollution has now become a major problem affecting the health of millions of people living near sawmills environment and could have remarkably high rates of cancer, thyroid disease as well as other health problems and have raised series of questions about a link to sawmill activities, but so far there's little evidence to prove or disprove this, it has also worsens Earth's ecosystems, weakens the economic security of countries, as well as leading to a mammoth worldwide disease burden, disability, as well as premature death. Hence, pollution is bringing global earth changing climate closer [32, 33, 34, 2, 3]. Fossil fuel combustion in middle-income and high-income nations, and biomass burning in inefficient cook stoves, open fires, agricultural burns, forest burning, sawmill activities as well as brick kilns that are out-dated in low-income nations accounting for $85 \%$ airborne particulate pollution as well as for nearly all pollution through sulphur and nitrogen oxides. Fuel combustion is an important greenhouse gas sources as well as short-lived climate pollutants which are the main anthropogenic drivers of human climate change [32, $35,36,37,3,38]$.

Pollution is expensive; it is accountable for productivity losses, health-care related costs, as well as costs associated with ecosystems damages. Despite the great magnitude of these costs, they have not been seen and are not recognised as caused by pollution [39]. The productivity losses of pollution-related diseases and health-related costs are buried in labour statistics and in hospital budgets [41]. As a result, the full pollution costs are underestimated and not treasured, are frequently not counted, as well as prohibitively not 
accessible toward rebutting one-sided, economically based conflict against the control of pollution $[31,42,2,1]$. The air pollution nature is changing as well as getting worse in many parts of the world, particularly at sawmill environment. These changes mirror improved energy consumption, improved use of novel equipment's as well as technologies, the swift industrialisation of middle-income and low-income nations, and the worldwide populations shift from the rural areas to large cities. Household air as well as pollution from water, the pollution forms that were conventionally associated with extreme poverty as well as historical lifestyles, are gradually declining. Yet, chemical pollution, ambient air pollution, as well as pollution from soil, are all increasing [43, 44]. The main causes of this type of pollutants are: the unrestrained development of cities [45]; increasing demands for energy [8]; increasing mining, smelting, and deforestation [7]; the worldwide toxic chemicals spread; increasingly heavier insecticides applications as well as herbicides $[29,47,46$, $48,49,50,31,51]$; and a progressively usage of fuel powered trucks, cars, as well as buses. The Increase in chemical pollution in soil and ambient air in the past 500 years is directly related toward the currently predominant, direct, take-make-use-dispose economic shift that Pope Francis call "throw away culture" [52], which natural resources as well as human capital have become more abundant as well as expendable, and the penalties of their irresponsible misuse are taken with little heed [53, 54].

The understanding of the science of environmental pollution and its impact on health has made great progress [40,55]. New technologies, including satellite imagery [82], have improved the capacity toward pollution mapping, measure the levels of pollution remotely, detect the patterns of pollution, as well as track seasonal path over combined time [55]. Sophisticated chemical analyses have provided a better understanding of pollution composition as well as elucidated relationship amongst disease as well as pollution [56]. Large potential, multi-year epidemiological research has shown that air pollution is linked by means of a greater number of major non-communicable diseases, especially hitherto known in the past. Pollution has now been recognized as a significant causative factor for numerous non-communicable diseases such as neurodevelopmental disorders, cancer, asthma as well as children with birth defects with chronic obstructive pulmonary disease, stroke, heart disease, as well as adult's cancer $[57,58]$. In the absence of an outstanding intervention, Unexpectedly, the mortality rate from air pollution will increase by more than $50 \%$ by 2050 [59]. Despite these scientific advances, much remains to be said about the effects of the pollution as well as their health effects. These shortcomings include the lack of information on measures taken in several countries to combat pollution as well as pollution-related disease prevalence and its effects; poor toxic effects on the knowledge of specific common use chemicals, particularly most recent chemicals classes [60, 61]; inadequate information toward exposures degree as well as disease burden linked by means of toxic exposures that contaminate sites as well as insufficient information to account for the probable delayed in the toxic effect's exposures sustained early in life [62]. The exact nature of the dose-response model used toward assessing disease risk linked by means of air pollution is unknown. For example, depending on the quality of fine-particulate air pollution, the structure of response group exposed both at low as well as very high levels of exposure is much less pronounced and the assumptions underlying the integrated response exposure function used toward estimating the fine particulate ( $\left.\mathrm{PM}_{2.5}\right)$ exposure absolute risks in both the Global Burden of Disease (GBD) study as well as WHO analyses which are not acknowledged to be accurate $[63,64]$.

\subsection{Objectives of the study}

This study aimed at assessing ambient air quality at Major Sawmill sites in Ilorin Metropolis, Kwara State, Nigeria.

To achieve this aim, the following specific objectives are to: 
1. Examine the relationship among $\mathrm{CO}(\mathrm{ppm}), \mathrm{PM}_{2.5}\left(\mathrm{ug} / \mathrm{m}^{3}\right), \mathrm{PM}_{10}(\mathrm{ug} / \mathrm{m} 3), \mathrm{H}_{2} \mathrm{~S}$ (ppm), VOC $(\mathrm{ppm})$, LEL $(\%)$, Formaldehyde $\left(\mathrm{mg} / \mathrm{m}^{3}\right)$, Oxygen $\left(\mathrm{O}_{2}\right)$, temperature $\left({ }^{\circ} \mathrm{C}\right)$ and relative humidity $(\mathrm{RH})$ in the study area.

2. Compare the air quality with the international and national acceptable standards.

3. Compare the concentrations of $\mathrm{CO}, \mathrm{PM}_{2.5}, \mathrm{PM}_{10}, \mathrm{H}_{2} \mathrm{~S}$, VOC, LEL, Formaldehyde, Oxygen $\left(\mathrm{O}_{2}\right)$, temperature and relative humidity.

4. Make the necessary recommendations from the findings to the residents of the major sawmills in Ilorin, Kwara State, Nigeria.

\section{Materials and Methods}

\subsection{Study area}

\subsubsection{Location}

The capital of Kwara State is Ilorin, lying between latitude $8^{\circ} 30^{\prime}$ and $8^{\circ} 50^{\prime} \mathrm{N}$ and at longitude $4^{\circ} 20^{\prime}$ and $4^{\circ} 35^{\prime} \mathrm{E}$ of the equator (see figure 1 below), with over one million population (2006 census). The city of Ilorin has an area of approximately $468 \mathrm{sqkm}$ and is located in the intermediate zone in the forest as well as the regions of guinea savannah of Nigeria. It is approximately $300 \mathrm{~km}$ from Lagos and $500 \mathrm{~km}$ from Abuja, the capital city of Nigeria. Its height is between 250 to $400 \mathrm{~m}$ above sea mean level. It is likewise the regional headquarters of the Ilorin West Local Government Area (LGA) which is encircled by other local government areas (LGAs) of the state. This position gives her the roles as the commercial as well as the organisational capital of the State, the control centre of Ilorin West LGA, and together with Ilorin South, Ilorin East, Asa and Moro LGAs, they constitute the Ilorin Emirate. The location of Ilorin west is revealed in Figure 1. Ilorin has many ethnic groups, especially the Yoruba, Kambari, Hausa, Fulani, Gobir, as well as Nupe, that constituted it. The diversity of multi-linguistic as well as multi-cultural nature of the people may perhaps remain traced toward their historical background. Ilorin is said to have been established as hamlets in $17^{\text {th }}$ century through an itinerant farmer named Ojo from Gambe near Oyo-Ile. The hitherto current hamlets remained in 1830s and fused under the Fulani hegemony sovereignty through Abdul-Salam, son of Sheikh Alimi. The entire population of the Ilorin West LGA was 365,221 in 2006. It included 180,387 males as well as 184,834 females; becoming the most populous LGA in Kwara State, with a growth rate of $3.0 \%[2,1]$. 


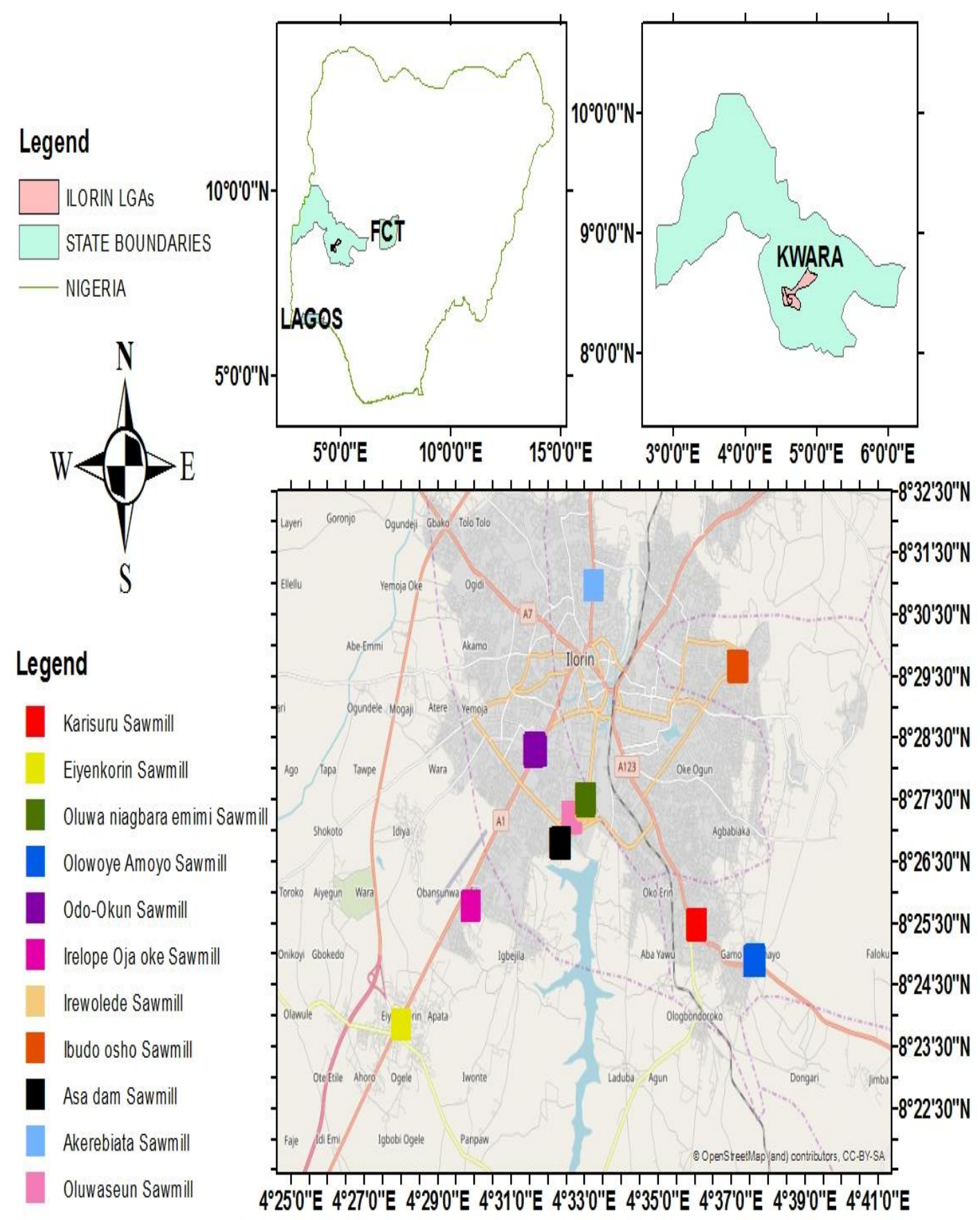

Figure 1. Map of Kwara State Showing the Study Area. [Adapted from http://dx.doi.org/10.22158/ees.v3n1p1.] [1]

\subsection{Climate}

The Ilorin climate is tropical in nature and is influenced by two trade winds that is dominant on the country. According to Olalekan et al. [2], the Ilorin climate is a tropical continental with the highest temperature all over the year. Ilorin is known to experienced rainy and dry seasons. It falls into the derived savannah vegetation, protected by means of the existence of dry lowland rain forest vegetation cover. The rainy season is between the month of March as well as October whereas the dry season is between November and February. The entire annual rainfall at the northern border of the country starts from 800 
to $1200 \mathrm{~mm}$, in the northwest of the state, having $950 \mathrm{~mm}$ to $1300 \mathrm{~mm}$ whereas the southeast is 1000 to $1500 \mathrm{~mm}$. Kwara state consists of several rivers including the Asa, Awonriver, Oshin and Moro rivers in the central state. Likewise, the average monthly temperature is generally higher during the year. The average daily temperatures in January are $25^{\circ} \mathrm{C}$, May $27.5^{\circ} \mathrm{C}$ and September $22.5^{\circ} \mathrm{C}$. Although the humidity is moderately high, rainfall amount in the south is moderately higher than that observed in the northern part of the study area.

\subsection{Vegetation}

Ilorin vegetation is usually located amongst the deciduous woodlands of southern Nigeria as well as the dry savannah of Nigeria. It fundamentally contains grass cover, shrubs as well as medium sized trees of the guinea savannah type [2]. The vegetation comprises of plant species like shear butter trees, locust beans trees, elephant grasses, shrubs and herbaceous plant among others are common in this area. The study area vegetation has partial rainforest, nonetheless many areas are savannah-like such as tall grasses as well as scattered trees.

\subsection{Topography and drainage}

Ilorin dendritic pattern of drainage system is owed to its characteristics. The most significant river is the Asa River which flows in the direction of south-north. Asa River is a fairly extensive valley and split Ilorin into two parts viz: Eastern as well as the Western part. The foremost rivers are Asa, Alalubosa, Agba, Osere, Okun as well as Aluko. Some of these rivers flow into the Niger river or Asa river [2, 1]. The overall land elevation in the western part ranges from $273 \mathrm{~m}$ to $364 \mathrm{~m}$ (that is 900 to 1/200 ft) above sea mean level. Toward the northwest of Ilorin exists a secluded hill identified as Sobi hill which is approximately $394 \mathrm{~m}$ high above the level of the sea. The River Niger has its natural boundary in the state, which is along northern and eastern margins as well as shares a common interior borderline with Niger State in the north, Kogi State in the east, Oyo, Ekiti and Osun States in the south as well as with the Republic of Benin in the west, as an international boundary. It is important to note that the state is undeniably a middle belt state which acts as a 'gateway' amongst the North and the South and literally is a "melting point" for the northern as well as southern cultures of a moderately flat and undulating land with interine as well as lacustrine deposits, sparsed hills and valleys in fragments of local government areas especially in Baruten, Kaiama as well as Moro.

\subsection{Land use}

The people's major occupation is mixed farming. The extensive vastness of arable as well as fertile soil and good climatic conditions contributing toward a wide diversity of clean foods and cash crops, with beans, yam, cashew, groundnut, vegetables varieties, maize as well as guinea corn. The existence of savannah type of vegetation made possible animals rearing. Other well-known economic activities are pottery making, cloth weaving, Shea butter production, blacksmithing, as well as gum processing.

\subsection{Sample collection}

Sample collections were limited to air quality. Air quality sources were randomly selected within the vicinity of the study area, but at different distances from each other for the purpose of this study. Also, the samples were collected at different locations. These locations include: Kanisuru Sawmill, Eiyenkorin Sawmill, Oluwaniagbaraemimi Saw mill, OlowoyeAmoyo Sawmill, Odo-okun Sawmill, Irelopeojaoke Sawmill, Irewolede Sawmill, Ibudo Osho Sawmill, Asa dam Sawmill, Akerebiata Sawmill, Oluwaseun Sawmill etc (Figure 1). The monitoring exercise were taken in the daytime, between 9.00am and 6.00pm.

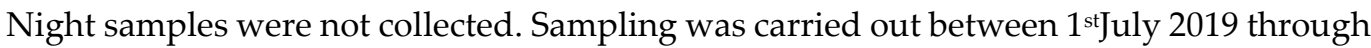


$1^{\text {st }}$ of August 2019 within major sawmill sites in Ilorin Metropolis, Kwara State, Nigeria each day for a period of one month on an alternate day.

\subsection{Equipment employed \\ 2.7.1. Handheld gas detector}

"Hand held mobile multi-gas monitor with model AS8900 (Carbon Monoxide (CO), Hydrogen Sulphide $\left(\mathrm{H}_{2} \mathrm{~S}\right)$, Combustile (LEL), and Oxygen $\left(\mathrm{O}_{2}\right)$, BLATN with model BR Smart Series air quality monitor (Particulate Matter ( $\left.\mathrm{PM}_{10}\right)$, Formaldehyde) and air quality multimeter with model B SIDE EET100 (Dust (PM2.5), VOC, Temperature and Relative Humidity) equipment will be used to detect the presence and precise quantity of the following individual gases, viz: Carbon Monoxide (CO), Particulate Matter ( $\mathrm{PM}_{2.5}$ ), Particulate Matter (PM10), Hydrogen Sulphide $\left(\mathrm{H}_{2} \mathrm{~S}\right)$, Volatile Organic Compound (VOC), Combustile (LEL), and Oxygen $\left(\mathrm{O}_{2}\right)^{\prime \prime}$.

\subsubsection{Global positioning system (GPS)}

"Spatial positioning of different sawmill locations was collected through the use of a hand-held Global Positioning System. The GPS was helpful in obtaining the selected areas in the community and data obtained was used to produce a digital map through the Arc view GIS software".

\subsection{Statistical analysis}

Mean, standard deviation and coefficient of variation were computed for each of the parameter (Oxygen, VOC, PM2.5, PM10, LEL, formaldehyde, temperature and relative humidity). Pearson correlation was used to establish relationship among the parameters. Also, relationship between these parameters and distance was explored using Pearson correlation. Levels of these parameters relative to their respective FMEV and WHO standards were compared for statistical significance using one sample t-test. Furthermore, data obtained was also analysed using multiple linear regression. Statistical significance was established at 0.05 level of significance with $p<0.05$ signifying statistical significance. All data analysis and computations of result was done using the Statistical Package for Social Sciences (SPSS version 22.0).

\section{Results}

Table 1 presents the correlation between the parameters. Result shows that the level of temperature in the study area has significant positive relationship with $\mathrm{HcHo}(\mathrm{r}=0.35$, $\mathrm{p}<0.05)$ and significantly negatively related to LEL $(\mathrm{r}=-0.53, \mathrm{p}<0.01)$. The concentration of VOC was found to be positively significantly related to $\mathrm{O}_{2}(\mathrm{r}=0.34, \mathrm{p}<0.01)$ while for $\mathrm{CO}(\mathrm{r}=-0.39, \mathrm{p}<0.01)$ and elevation $(\mathrm{r}=-0.32, \mathrm{p}<0.01)$, significant negative relationship was obtained. There was a significant positive relationship between $\mathrm{PM}_{2.5}$ and $\mathrm{CO}(\mathrm{r}=0.38$, $\mathrm{p}<0.01), \mathrm{PM}_{10}$ and $\mathrm{CO}(\mathrm{r}=0.37, \mathrm{p}<0.01)$, elevation and $\mathrm{CO}(\mathrm{r}=0.37, \mathrm{p}<0.01)$ while between $\mathrm{O}_{2}$ and $\mathrm{CO}$, a negative but significant relationship was obtained $(\mathrm{r}=-0.35, \mathrm{p}<0.01)$. Result reveals that for $\mathrm{O}_{2}$ there is a significant positive relationship with $\mathrm{HcHo}(\mathrm{r}=0.26, \mathrm{p}<0.05)$ but significant negative relationship with elevation $(r=-0.54, p<0.05)$. There was a significant positive relationship between $\mathrm{PM}_{10}$ and $\mathrm{PM}_{2.5}(\mathrm{r}=0.99, \mathrm{p}<0.01)$, HcHo and $\mathrm{PM}_{2.5}(\mathrm{r}=$ $0.44, \mathrm{p}<0.01)$ while positive significant relationship was established between $\mathrm{HcHo}$ and $\mathrm{PM}_{10}(\mathrm{r}=0.44, \mathrm{p}<0.01)$. Elevation shows significant negative relationship with LEL $(\mathrm{r}=-$ $0.37, \mathrm{p}<0.01)$. 
Table 1. Correlation between the Variables in the Study Area (Kwara State).

\begin{tabular}{ccccccccccc}
\hline Variables & 1 & 2 & 3 & 4 & 5 & 6 & 7 & 8 & 9 & 10 \\
\hline Temp $\left({ }^{\circ} \mathrm{C}\right)$ & 1 & & & & & & & & \\
RH & 0.02 & 1 & & & & & & & \\
VOC $(\mathrm{ppm})$ & -0.28 & -0.03 & 1 & & & & & & \\
$\mathrm{CO}(\mathrm{ppm})$ & -0.14 & 0.06 & $-0.39^{* *}$ & 1 & & & & & \\
$\mathrm{O}_{2}$ & -0.18 & 0.07 & $0.34^{* *}$ & $-0.35^{* *}$ & 1 & & & & \\
$\mathrm{PM}_{2.5}\left(\mathrm{ug} / \mathrm{m}^{3}\right)$ & 0.07 & -0.08 & -0.13 & $0.38^{* *}$ & -0.18 & 1 & & & \\
$\mathrm{PM} 10\left(\mathrm{ug} / \mathrm{m}^{3}\right)$ & 0.05 & -0.12 & -0.15 & $0.37^{* *}$ & -0.07 & $0.99^{* *}$ & 1 & & \\
HcHo $\left(\mathrm{mg} / \mathrm{m}^{3}\right)$ & $0.35^{*}$ & 0.03 & 0.18 & 0.08 & $0.26^{*}$ & $0.44^{* *}$ & $0.44^{* *}$ & 1 & & \\
LEL $(\%)$ & $-0.53^{*}$ & -0.06 & 0.17 & -0.06 & 0.23 & -0.18 & -0.15 & 0.02 & 1 & \\
Elevation & 0.18 & -0.16 & $-0.32^{* *}$ & $0.37^{* *}$ & -0.54 & 0.06 & 0.06 & -0.21 & -0.37 & 1 \\
\hline
\end{tabular}

**Significant at $1 \%(\mathrm{p}<0.01),{ }^{*}$ significant at $5 \%(\mathrm{p}<0.05)$.

Table 2 presents results of the comparison of the air quality parameters in the study area (Kwara state) with that of the recommended standards as provided by the Federal Ministry of Environment (FMEV) and World Health Organisation (WHO). Result shows that temperature and relative humidity in the study area were higher than the lowest acceptable standard but lower than the highest acceptable. The level of VOC and LEL were above the recommended FMEV standards while $\mathrm{CO}, \mathrm{O}_{2}, \mathrm{PM}_{2.5}, \mathrm{PM}_{10}$ were below FMEV standards. In relation to $\mathrm{WHO}$ standards, result shows that VOC, PM2.5, P.M10 were above the standard while $\mathrm{O}_{2}, \mathrm{HcHo}$ and LEL were below the recommended WHO standards.

Table 2. Comparison of Air quality in the study area (Kwara State) with the recommended acceptable standards.

\begin{tabular}{ccccccc}
\hline Air quality parameters & $\mathbf{n}$ & Range & Mean & SD & FMEV & WHO Standards \\
\hline Temperature & 75 & $21.00-46.40$ & 28.27 & 7.19 & $29.5-36.9$ & - \\
Relative humidity & 75 & $36.40-53.50$ & 43.46 & 4.84 & $4.90-75.9$ & - \\
VOC & 75 & $0.00-31.00$ & 4.87 & 9.06 & 0.50 & 0.50 \\
CO & 75 & $0.00-23.00$ & 5.44 & 7.12 & 50 & 50 \\
$\mathrm{O}_{2}$ & 75 & $20.50-21.10$ & 20.86 & 0.10 & 20.9 & $>23.5$ \\
PM$_{2.5}$ & 75 & $0.37-999.00$ & 91.71 & 118.81 & 115 & 75 \\
PM10 & 63 & $0.50-999.00$ & 107.78 & 125.38 & 150 & 100 \\
HcHo & 63 & $0.00-0.10$ & 0.02 & 0.02 & $0.1-3.1$ & 30.0 \\
LEL & 66 & $5.00-15.00$ & 10.61 & 1.53 & 5 & 15.5 \\
\hline
\end{tabular}

Result shows that there is no significant difference in relative humidity, $\mathrm{PM}_{2.5}, \mathrm{PM}_{10}$, $\mathrm{O}_{2}$ and HcHo between the eleven locations ( $p>0.05$ ) (Table 3a and $b$ ). The mean temperature in OdoOkun was significantly higher than that obtained in other locations while between Karisunu, IbudoOsho, Irewolede and Oluwaseun, no significant difference was established in their mean temperature. The level of VOC in Oluwaniagbaraemimi, Asadam and Irewolede were significantly higher than that obtained in other locations $(\mathrm{p}<0.05)$ while between other location, there were no significant difference in VOC ( $p>0.05)$. Result also shows that Eyenkorin and IrelopeOjaOke reported significant higher level of $\mathrm{CO}$ compared with other locations ( $\mathrm{p}<0.05)$. The level of LEL in Odo-okun was significantly less than that obtained in other locations $(\mathrm{p}<0.05)$ while elevation in Eyenkorin and IrelopeOjaOke were significantly higher than that of other locations $(\mathrm{p}<0.05)$. 
Table 3a. Comparison of the air quality parameters in the study area of Kwara State (Temperature, $\mathrm{RH}, \mathrm{VOC}, \mathrm{CO}, \mathrm{O}_{2}$ and $\mathrm{PM}_{2.5}$ ).

\begin{tabular}{cccccccc}
\hline S/N & Locations & $\begin{array}{c}\text { Tempera- } \\
\text { ture }\left({ }^{\circ} \mathbf{C}\right)\end{array}$ & RH & VOC (ppm) & CO (ppm) & $\mathbf{O}_{2}$ & $\mathbf{P M}_{2.5}\left(\mathbf{u g} / \mathbf{m}^{3}\right)$ \\
\hline 1 & Asadam & $23.88 \pm 1.25^{\mathrm{a}}$ & $42.65 \pm 5.11^{\mathrm{a}}$ & $15.05 \pm 10.08^{\mathrm{b}}$ & $0.00 \pm 0.00^{\mathrm{a}}$ & $20.90 \pm 0.05^{\mathrm{a}}$ & $54.00 \pm 12.08^{\mathrm{a}}$ \\
2 & Karisunu & $28.29 \pm 2.45^{\mathrm{b}}$ & $40.87 \pm 4.24^{\mathrm{a}}$ & $0.29 \pm 0.18^{\mathrm{a}}$ & $7.71 \pm 5.65^{\mathrm{b}}$ & $20.84 \pm 0.05^{\mathrm{a}}$ & $75.29 \pm 15.17^{\mathrm{a}}$ \\
3 & IbudoOsho & $28.00 \pm 1.29^{\mathrm{b}}$ & $43.54 \pm 4.80^{\mathrm{a}}$ & $0.30 \pm 0.23^{\mathrm{a}}$ & $8.00 \pm 7.42^{\mathrm{b}}$ & $20.87 \pm 0.05^{\mathrm{a}}$ & $204.95 \pm 353.58^{\mathrm{a}}$ \\
4 & Irewolede & $27.67 \pm 1.21^{\mathrm{b}}$ & $41.15 \pm 4.65^{\mathrm{a}}$ & $18.70 \pm 10.08^{\mathrm{b}}$ & $1.17 \pm 2.86^{\mathrm{a}}$ & $20.88 \pm 0.08^{\mathrm{a}}$ & $66.83 \pm 12.11^{\mathrm{a}}$ \\
5 & Oluwaseun & $27.13 \pm 1.96^{\mathrm{b}}$ & $45.81 \pm 4.78^{\mathrm{a}}$ & $0.23 \pm 0.05^{\mathrm{a}}$ & $2.91 \pm 8.12^{\mathrm{a}}$ & $20.86 \pm 0.07^{\mathrm{a}}$ & $42.60 \pm 29.59^{\mathrm{a}}$ \\
6 & OdoOkun & $43.46 \pm 2.84^{\mathrm{c}}$ & $44.08 \pm 5.33^{\mathrm{a}}$ & $0.47 \pm 1.34^{\mathrm{a}}$ & $4.17 \pm 6.69^{\mathrm{b}}$ & $20.81 \pm 0.14^{\mathrm{a}}$ & $104.42 \pm 91.99^{\mathrm{a}}$ \\
7 & Eyenkorin & $22.00 \pm 1.26^{\mathrm{a}}$ & $44.60 \pm 4.28^{\mathrm{a}}$ & $0.22 \pm 0.08^{\mathrm{a}}$ & $13.17 \pm 6.46^{\mathrm{c}}$ & $20.77 \pm 0.10^{\mathrm{a}}$ & $93.00 \pm 4.73^{\mathrm{a}}$ \\
8 & IrelopeOjaOke & $22.00 \pm 1.00^{\mathrm{a}}$ & $40.23 \pm 4.72^{\mathrm{a}}$ & $0.20 \pm 0.01^{\mathrm{a}}$ & $16.00 \pm 0.00^{\mathrm{c}}$ & $20.73 \pm 0.21^{\mathrm{a}}$ & $89.67 \pm 2.08^{\mathrm{a}}$ \\
9 & Oluwaniag- & $24.00 \pm 1.41^{\mathrm{a}}$ & $44.60 \pm 4.28^{\mathrm{a}}$ & $19.20 \pm 9.79^{\mathrm{b}}$ & $0.00 \pm 0.00^{\mathrm{a}}$ & $20.95 \pm 0.08^{\mathrm{a}}$ & $56.17 \pm 15.88^{\mathrm{a}}$ \\
10 & OluwoyeAmoyo & $23.83 \pm 1.33^{\mathrm{a}}$ & $47.03 \pm 4.50^{\mathrm{a}}$ & $0.21 \pm 0.02^{\mathrm{a}}$ & $6.33 \pm 9.81^{\mathrm{b}}$ & $20.88 \pm 0.04^{\mathrm{a}}$ & $69.33 \pm 17.52^{\mathrm{a}}$ \\
11 & AkereBiata & $24.33 \pm 1.03^{\mathrm{a}}$ & $41.12 \pm 4.59^{\mathrm{a}}$ & $0.40 \pm 0.21^{\mathrm{a}}$ & $8.83 \pm 4.54^{\mathrm{b}}$ & $20.88 \pm 0.04^{\mathrm{a}}$ & $151.67 \pm 76.19^{\mathrm{a}}$ \\
\hline
\end{tabular}

Similar superscript means not significantly different $(\mathrm{p}>0.05)$, different superscript means significantly different $(\mathrm{p}<0.05)$.

Table 3 b. Comparison of the air quality parameters in the study area of Kwara State (Temperature, $\mathrm{RH}, \mathrm{VOC}, \mathrm{CO}, \mathrm{O}_{2}$ and $\mathrm{PM}_{10}$ ).

\begin{tabular}{cccccc}
\hline $\mathbf{S} / \mathbf{N}$ & Locations & PM10 $\left(\mathbf{u g} / \mathbf{m}^{3}\right)$ & HcHo $\left(\mathbf{m g} / \mathbf{m}^{3}\right)$ & LEL $\mathbf{( \% )}$ & Elevation \\
\hline 1 & Asadam & $66.50 \pm 15.55^{\mathrm{a}}$ & $0.01 \pm 0.01^{\mathrm{a}}$ & $11.00 \pm 0.00^{\mathrm{b}}$ & $325.67 \pm 5.64^{\mathrm{a}}$ \\
2 & Karisunu & $112.71 \pm 55.98^{\mathrm{a}}$ & $0.02 \pm 0.01^{\mathrm{a}}$ & $10.57 \pm 0.79 \mathrm{~b}$ & $386.31 \pm 9.31^{\mathrm{a}}$ \\
3 & IbudoOsho & $228.29 \pm 342.21^{\mathrm{a}}$ & $0.04 \pm 0.04^{\mathrm{a}}$ & $10.71 \pm 0.76^{\mathrm{b}}$ & $317.00 \pm 9.59^{\mathrm{a}}$ \\
4 & Irewolede & $73.83 \pm 18.31^{\mathrm{a}}$ & $0.05 \pm 0.03^{\mathrm{a}}$ & $11.00 \pm 0.00^{\mathrm{b}}$ & $299.43 \pm 7.19^{\mathrm{a}}$ \\
5 & Oluwaseun & $43.88 \pm 28.54^{\mathrm{a}}$ & $0.03 \pm 0.03^{\mathrm{a}}$ & $12.00 \pm 1.85^{\mathrm{b}}$ & $344.24 \pm 10.79^{\mathrm{a}}$ \\
6 & OdoOkun & - & $5.00 \pm 0.00^{\mathrm{a}}$ & $983.60 \pm 33.86^{\mathrm{b}}$ \\
7 & Eyenkorin & $119.33 \pm 11.00^{\mathrm{a}}$ & $0.01 \pm 0.00^{\mathrm{a}}$ & $10.33 \pm 0.52 \pm 0.52^{\mathrm{b}}$ & $1153.50 \pm 7.87^{\mathrm{c}}$ \\
8 & IrelopeOjaOke & $108.00 \pm 6.93^{\mathrm{a}}$ & $0.01 \pm 0.01^{\mathrm{a}}$ & $9.67 \pm 0.58^{\mathrm{b}}$ & $1814.67 \pm 1217.29^{\mathrm{c}}$ \\
9 & Oluwaniagbaraemimi & $71.17 \pm 24.27^{\mathrm{a}}$ & $0.03 \pm 0.02^{\mathrm{a}}$ & $11.00 \pm 0.00^{\mathrm{b}}$ & $308.92 \pm 8.46^{\mathrm{a}}$ \\
10 & OluwoyeAmoyo & $87.67 \pm 22.11^{\mathrm{a}}$ & $0.02 \pm 0.02^{\mathrm{a}}$ & $11.00 \pm 0.00^{\mathrm{b}}$ & $378.00 \pm 12.78^{\mathrm{a}}$ \\
11 & AkereBiata & $180.67 \pm 89.23^{\mathrm{a}}$ & $0.03 \pm 0.03^{\mathrm{a}}$ & $10.50 \pm 0.55^{\mathrm{b}}$ & $789.05 \pm 381.95$ \\
\hline
\end{tabular}

Similar superscript means not significantly different $(\mathrm{p}>0.05)$, different superscript means significantly different $(\mathrm{p}<0.05)$.

\section{Discussion}

\subsection{Bivariate relationship between air quality parameters}

The wood processing activities and furniture making at sawmills involve the use of various chemicals (adhesives, thinners, paints, preservatives, etc). These chemicals release VOCs into the ambient air, thus increasing the concentration levels of photochemical oxidants. Specifically, the Pearson's correlation coefficient of air quality parameter as shown in Table 1 reveals more precisely the nature and strength of bivariate relationship between the variables in the sample. There exists significantly strong positive correlation between PM10 concentration and $\mathrm{PM}_{2.5}(0.99, \mathrm{p}<0.01)$ and carbon dioxide $(\mathrm{CO})(0.37, \mathrm{p}<0.01)$ concentrations between oxygen $\left(\mathrm{O}_{2}\right)$ concentration and volatile organic compounds (VOC) concentration $(0.34, \mathrm{p}<0.01)$ between the concentration of $\mathrm{PM}_{2.5}$ and carbon dioxide $(\mathrm{CO})$ concentration $(0.38, \mathrm{p}<0.01)$ between the concentration of Formaldehyde $(\mathrm{HcHo})$ and $\mathrm{PM}_{10}$ $(0.44, \mathrm{p}<0.01)$ and $\mathrm{PM}_{2.5}(0.44, \mathrm{p}<0.01)$ concentration between Elevation and carbon dioxide 
concentration $(0.37, \mathrm{p}<0.01)$ respectively. This finding agrees with highly significant values recorded by Olalekan et al. [2] in their studies on assessment of air quality indices and its health impacts in Ilorin metropolis, Kwara State, Nigeria. This result implies that as $\mathrm{PM}_{10}$ in the sawmill environment increases, the $\mathrm{PM}_{2.5}$ increases significantly, As Formaldehyde $(\mathrm{HcHo})$ increases, $\mathrm{PM}_{10}$ and $\mathrm{PM}_{2.5}$ increase significantly, as Oxygen $\left(\mathrm{O}_{2}\right)$ increases volatile organic compound (VOC) increases, as carbon dioxide (CO) increases $\mathrm{PM}_{10}$ and $\mathrm{PM}_{2.5}$ concentration increases. This may be due to the pollutant's reaction or interplay in the planetary boundaries. Similarly, there exists significantly positive correlation between Formaldehyde $(\mathrm{HcHo})$ concentration and temperature $(0.35, \mathrm{p}<0.05)$ and oxygen $(0.26$, $\mathrm{p}<0.05)$ concentrations. However, there was a significantly negative correlation between carbon dioxide $(\mathrm{CO})$ concentration and volatile organic compound (VOC) concentration $(\mathrm{p}<0.01)$ and between oxygen $\left(\mathrm{O}_{2}\right)$ concentration and carbon dioxide $(\mathrm{CO})(\mathrm{p}<0.01)$, between combustible (LEL) concentration and temperature $(\mathrm{p}<0.05)$, and between elevation and volatile organic compound $(\mathrm{VOC})(\mathrm{p}<0.01)$ concentration. This implies that, as volatile organic compound (VOC) and oxygen concentration increases, carbon dioxide (CO) decreases considerably, as temperature increases combustible (LEL) concentration decreases significantly and as VOC concentration increases elevation decreases significantly. This may be attributed to the toxic nature of these pollutants.

\subsection{Air quality comparison with recommended acceptable standards}

Given the evidence for the impact of air pollution on health, concerns around the outdoor air-quality have led to little developmental progress regardless of low-cost monitoring air-quality systems. These systems are able to track numerous real time contaminants, inform users near recent air-quality status conditions and collect data sent to the central server. Yet, most Internet of Things (IoT) time-tracking systems are far enough away to detect the impact of pollution, causing problems for many general users to find out about the polluted air. Hence, the most significant portion of the emission record is the certification with good data on ambient air quality. It is impossible to accurately estimate emissions from every part of the region, particularly where sources change over time as well as in space, because emission inventories are constructed on the basis of different assumptions as well as missing information projections. The primary information is generally presented yearly. The fact, then, is that the inventories reflect the time dynamics as well as space. Statistically, validated emissions can be used in conjunction with concentrations attained with acceptable standards and models. However, formulation of air quality models must be borne in mind on the basis of the concept of atmospheric conditions. The greatest qualitative technique for estimating emissions is compared to the trend regarding concentrations observed in the ten-year study, as in the current study. Olalekan et al. [2] attempted toward validating emissions from industrial locations of Temidire Irewolede Community (TIC) at 24 locations for eight weeks using favourable monitoring air quality data to analyze sampling stations in Kwara State. In this study, the level of emission estimates as well as concentrations of Particulate Matter ( $\left.\mathrm{PM}_{2.5}\right)$, Carbon monoxide $(\mathrm{CO})$, Particulate Matter $\left(\mathrm{PM}_{10}\right)$, Formaldehyde, Oxygen $\left(\mathrm{O}_{2}\right)$, temperature $\left(\mathrm{O}^{\circ} \mathrm{C}\right)$, Volatile organic compound (VOC), Combustible (LEL) as well as relative humidity (RH) in the study area are compared with same pollutants as the acceptable standards recommended at monitoring station, for the period of two months. The oxygen analysis attained in the study area did not differ remarkably from that of FMEV standard, but remained well remarkably below the WHO standard. This study is based on a report by Olalekan et al. [2] who showed that the level of oxygen attained in the area studied and did not differ remarkably from FMEV standard $(\mathrm{p}=0.075, \mathrm{p}>0.05)$ but was remarkably higher than the WHO standard $(\mathrm{p}<0.0001)$. However, this current study show oxygen level is above the recorded oxygen level reported by Olalekan et al., [2]. The results also showed that the 
combustible (LEL) level was remarkably lower than the value accepted by the WHO, but did not change significantly from the FMEV standard. Such findings confirm the results of qualitative and quantitative analysis results, indicating that VOCs level are twice as high as the FMEV and WHO standard. The elevated VOCs presented in these studies, particularly with regard to the occupational health conditions of sawmill workers is alarming, even though consistent with findings of the obtained results of previous works $[1,2]$. High levels of VOCs concentration can cause respiratory difficulties as well as could cause distress toward asthmatics between industrial workers. This assumption is consistent with the critical values reported by Raimi et al. [37] based on their studies on "assessment of air quality indices and its health impacts in Ilorin metropolis, Kwara State, Nigeria". This can be explained by a large number of finely divided solids that can be released into the air during the process of combustion as well as activities of sawmill at the sawmill environment, industrial activities or natural sources. The remarkable difference in urbanization level, or the remarkable difference in physiographic characteristics may perhaps be associated with the saw mill sources and planned burns as well as it may well remain referenced against well-known facts [32, 2, 1, 9]. Despite, regardless of the homogeneity of outcomes from these sawmills likewise its configuration, it could be influenced through intrinsic deterministic nature. These primary anthropogenic pollutants react with VOCs particularly, $\mathrm{SO}_{2}, \mathrm{NOx}$ as well as compounds of anthropogenic organic carbon toward creating haze of pollutants that are secondary in nature (Olalekan et al., [2]. The mean concentration of VOC in the air of the sawmill environment is 4.87 . This is higher than the mean value of 1.20 reported by Raimi et al. [1] in their study. This can be ascribed to tree filing, soot as well as smoke resulting from sawmill environment, which poses a health problem to the residents and the environmental sustainability of the people in the area. This study corroborates with highly remarkable values documented by Tawari and Abowei [65] as well as Olalekan et al. [2] in their studies. The actual damage to health caused through dust particles depends on their nature as well as composition. The outcome also showed that the combustible (LEL) level was remarkably lower than that of acceptable WHO value but did not differ remarkably from the standard of FMEV. These studies support the results of qualitative as well as quantitative analysis, demonstrating that the VOC level was remarkably higher than the standard specify by FMEV and WHO. The high level of VOCs results as described, particularly with regard to occupational health of sawmill workers is worrisome, though consistent with the results attained from preceding works [1]. High levels of VOCs concentration could cause respiratory problems as well as cause distress toward asthmatics workers in the sawmill industry. These results are consistent with the highly remarkable values reported by Raimi et al. [1] in their studies on "assessment of air quality indices and its health impacts in Ilorin metropolis, Kwara State, Nigeria". According to the Indian Health Care Institute, the number of patients with respiratory problems in Delhi hospitals is alarming. In addition, the mean concentrations of $\mathrm{PM}_{2.5}$ and $\mathrm{PM}_{10}$ in the studied samples were 91.71 and 107.78 respectively. This is worth more than the mean value of 64.58 and 43.22 given by Olalekan et al., [2] in their study. This circumstance should be anticipated toward having adverse health implications on the performance of sawmill employees. Prolonged exposure to elevated levels of PM10 concentration can cause sore throat as well as lung irritation, bronchitis and possibly lead to premature death. Similarly, a study by Carnegie Mellon University, state that the loss of more than $5 \%$ of cases is due to particulate matter ( $\left.\mathrm{PM}_{2.5}\right)$ pollution and is linked to 9,700 premature deaths in the United States. In the United States, the annual average of $\mathrm{PM}_{2.5}$ is down by $24 \%$ from 2009 to 2016 and up by 5\% from 2016 to 2018. They see an increase in $\mathrm{PM}_{2.5}$ in the amount of premature adults' deaths above the age of 30 by around 9,700 from 2016 toward 2018, with $80 \%$ of premature deaths happening among the elderly. 
Compared to his death from the EPA's statistical life value, researchers found that these deaths cost the economy $\$ 89 \mathrm{bn}$ in assets. Researchers believe that there are three main reasons for the country upsurge in $\mathrm{PM}_{2.5}$ pollution: Economic transformation due to increased oil consumption as well as their economic and social impact, including growth in the number of miles travelled in fossil-fuel-powered vehicles, which can likely contribute to increased $\mathrm{PM}_{2.5}$ in some counties, while lower coal-fired power will reduce in some areas; the wildfires increase in some parts of the West as well as Midwest, the numbers of rising wildfires at this moment were linked to the upsurges in fine particulate matter; violation of the enforcement decline in the Clean Air Act, researchers found that the most frequent enforcement type of the Clean Air Act decreased from 2009 to 2016 and continued to decreased from 2016 to 2018. Hence, the health consequences of this upsurge are remarkable. The deaths toll as well as the risks highlight air pollution importance as a vital as well as timely policy issue. What's more, their research suggests that a recent rise in fine particulate matter tend to have considerable effects on the increased risks of premature death. These increases are another tragedy that should coax decision makers to make policies that will help extend the life expectancy of children born and to combat an estimated 4.2 million premature deaths worldwide that are associated to ambient air pollution, especially heart disease, stroke, chronic obstructive pulmonary disease, chronic obstructive pulmonary disease and respiratory diseases in children and to take all necessary action toward maintaining and tackling the problem of air pollution. However, the results of this study contradict the findings of Olalekan et al., [2], stating that $\mathrm{PM}_{2.5}$ and $\mathrm{PM}_{10}$ were both remarkably and relatively low compared to FMEV standards and respectively higher than the standards of $\mathrm{WHO}$, hence the air in the sawmill environment has met the "low health category" considering the FMEV standards and posing no threat to the health as well as the milieu. Meaning that the $\mathrm{PM}_{2.5}$ and $\mathrm{PM}_{10}$ particles levels in the air could be wellthought-out to be relatively healthy for the inhabitant of the sawmill communities as well as everyone. However, Both $\mathrm{PM}_{2.5}$ and $\mathrm{PM}_{10}$ are respectively higher than WHO standards, thus could results in a call to public health action and should be given utmost attention for the reason that the current concentration may perhaps be due to the results of anthropogenic activities of the sawmill industry present in the study area. The measured concentration of $\mathrm{PM}_{2.5}$ and $\mathrm{PM}_{10}$ seem highly significant and the cumulative effect could be detrimental to health. Remarkably, the particulate matter sources can be natural or manmade. Some particulates emerge naturally, originating from dust storms, volcanoes, forest as well as grassland fires, living vegetation as well as sea spray. Activities of human, like the fossil fuels burning in vehicles, power plants and other industrial processes also generate substantial aerosols amounts. Anthropogenic aerosols globally are those made by the activities of humans presently accounting for approximately $10 \%$ of the aerosols over-all amount in the atmosphere. Elevated fine particles levels in the air are associated to the health hazards for example heart disease which impair function as well as lung cancer $[66,2,77,78,79,80,81]$. Free radicals that are persistent are associated with airborne fine particles that could lead to cardiopulmonary disease [67, 2]. Although, the measured concentrations of $\mathrm{CO}$ in air around the saw mills investigated were below the instrument detection limit. Carbon monoxide in air is the product of incomplete combustion, which is primarily released from the emissions of vehicles and generators. Although, it sources is not solely from the exhaust of the operating power generating set, since air current may contain intractable concentration from diffuse sources. Carbon monoxide values were expected to be high due to high traffic flow and continuous releases of vehicular emissions in around most of the saw mills. Although the measured concentration levels of $\mathrm{CO}$ were well below the set FMENV ambient air limits of $10 \mathrm{ppm}$, atmospheric $\mathrm{CO}$ is of apprehension due to its obvious human health and climatic effects. This is because most of the saw 
mills are located within residential and commercial areas. Carbon monoxide inhalation causes muscular weakness, weakens thinking as well as leads to drowsiness through reducing the carrying capacity of oxygen in the blood. It is also associated with increase in the possibility of exercise associated pain in the individuals with coronary heart disease. $\mathrm{CO}$ is a recognised neurotoxin, as well as there is a possibility for chronic exposure toward exerting neurologic effects. Moreover, it has been linked with the effects on prenatal as well as early postnatal mortality as well as birth defects in children of women exposed during pregnancy. These effects are presumably because of oxygen deprivation.

\subsection{Air quality parameters comparison}

Pollution from air is a well-known worldwide environmental problem affecting urban environment around the globe. Several monitoring programmes have been developed to determine air quality by providing detailed amount of data on the air pollutant concentration of each (e.g., HcHo, LEL, $\mathrm{O}_{2}$, VOC, $\mathrm{PM}_{2.5}, \mathrm{PM}_{10}$, Temperature, Relative Humidity etc.) in different world parts. The huge data frequently fails to deliver air quality status to government officials, scientific community, decision makers, and especially to the overall public in a straightforward and simple manner. Series of research show that prolonged exposures toward ambient air pollution increases the peril of being susceptible toward air borne diseases for instance respiratory disease, cardiovascular disease as well as lung cancer $[68,1]$. Consistently air pollution has been associated with a considerable burden of ill-health in both developed as well as emerging countries [69, 2, 1]. Notwithstanding the time differences as well as location, there remain limited statistically substantial differences in the levels of temperature (OdoOkun), VOCs (Oluwaniagbaraemimi, Asadam, Irewolede), CO (Eyenkorin, Irelopeojaoke) as well as elevation (Eyenkonrin, Irelopeojaoke) etc. Geographic studies suggest methodical differences in community exposure. For example, levels of VOC are higher in Oluwaniagbaraemimi; Asadam, the Irewolede area were remarkably higher than the one attained in other locations $(\mathrm{p}<0.05)$. This study concentration was higher when compared to the value described by Olalekan et al. [2] for the Temidere Irewolede Community (TIC) $\left(1.20 \mu \mathrm{g} / \mathrm{m}^{3}\right)$ in Ilorin Metropolis, Kwara State, Nigeria. The results of the current study suggest that there is spatial variability in the concentration of VOC between the selected study sites and the results of the CO gotten from the current study suggesting that there exist a spatial (site to site) variation of the concentration of $\mathrm{CO}$, although the general trend of $\mathrm{CO}$ concentration in Eyenkorin as well as Irelopeojaoke reported a substantial higher CO level compared to other saw mills locations $(p<0.05)$; this sawmill is one of the busiest route as well as business center and interstate cross bus stations, thus, it can be indirectly due to the increased vehicle congestion around Eyenkorin as well as Irelopeojaoke. The high $\mathrm{CO}$ values found near sawmill at Eyenkorin as well as Irelopeojaoke are not astonishing considering the fossil fuels volume consumed each day to power various devices, added to sawdust disposal as well as other wood wastes through open incineration. These on-going activities release countless gaseous pollutants together with $\mathrm{CO}$ which can lead to lungs and irritation of respiratory tracts as well as adversely affecting employee's defence system against pathogens as well as elevate the respiratory tract infections risk [30, 77, 78, 81]. Hence, polluted air is a global major threat to environmental health and contributes to more than 4,000 London residents who died in 2019, according to a study by researchers at Imperial College London. Research has shown that outside of London's districts most deaths occur due to air pollution, especially older people living in these areas, who are at risk of air pollution. However, the researchers found that between the year 2016 and 2019, the number of public primary and secondary schools in areas that exceeded the legal limit decreased by $97 \%$. Meaning that the average life expectation of children born in London in the year 2013 will increase by six months. Despite this remarkable increase, researchers say air pollution levels remain 
high. Currently, 99\% of those who do not follow World Health Organization (WHO) guidelines recommend a limit of $\mathrm{PM}_{2.5}$, which adds to the evidence-gathering and the organization's agreement that makes this limit to be included in the environment bill as a legally binding target to be met for 2030. The report clearly reminds us that air pollution reflects public health conditions and requires urgent action. Obviously, pollution is not just a city problem, because dying from air pollution is a sad reminder that the human cost of pollution from air pollution is real as well as very personal. However, several researchers have also noted that air pollution caused by wood burning was positively linked with emergency clinical pneumonia visits [70, 71, 8]. A mechanistic theory, which is consistent with the results of this study, asserts the growth of preterm births, respiratory symptoms, reduced lung function and increased use of asthma medication [72, 73, 74, 75] may be related to the high PSI (pollutant standard index) value obtained, which described the air quality ambient at Eyenkorin as well as Irelopeojaoke sawmill as unhealthful. Evidence-based practices and environmental monitoring show that low-income as well as vulnerable groups together with children face high levels of VOCs, $\mathrm{CO}$ as well as particulates in Irelopeojaoke, Asadam, Irewolede, Oluwaniagbaraemimi, Eyenkorin. Odookun saw mill also received higher temperature as well as was much remarkably higher than what was gotten in other locations. Even if the temperature is increasing on average around the world, it can be used as a surrogate measure of the meteorological aspects influencing the formation of surface ozone [76]. Our findings show a trend of temperature increase as well as these rising temperatures could potentially lead to deaths of thousands of people and the loss of billions of naira. Humidity as well as temperature are well known predictors of mortality and were important aspects in these studies and this temperature change is greater than that observed in other saw mills. The difference indicates long-term adaptability toward local climate, as well as highlights the significant of careful adjustment of site-specific temperature conditions while assessing the impact of other environmental stresses like air pollution. Likewise, the highest elevation was reported in Eyenkorin, Irewolopeojaoke as well as were remarkably higher than other locations $(\mathrm{p}<0.05)$. The LEL level in Odo-Okun was remarkably lower than that obtained in other locations $(\mathrm{p}<0.05)$.

\section{Conclusion}

Sawmill development usually targets poor communities, but remains a hotspot, with emissions rising per square mile, thus contributing to some of the nation's worst toxic air pollution, which is now considered a major health threat to the environment. Nigeria Ministry of Environment as well as the National Environmental Standard Regulatory and Enforcement Agency (NESREA) has a longstanding societal commitment toward safeguarding its nation health from the adverse effects of toxic agents in the milieu. This is mirrored in the missions, mandates, as well as the actions of its federal regulatory agencies. Thus, the needs to do a better job of identifying polluters including pollution profiteers and polluters paradise that don't appropriately report emission violations, as well as enforcing those violations more violently. Legally, at the level of the state, a number of regulatory agencies play a key role in addressing the threat of air pollution which could strengthen its monitoring as well as enforcement processes through identifying violations as well as issuing enforcement actions in a timelier manner. However, at the level of the policy, a pattern of initial success is been witnessed, excitement, as well as hype around a potentially effective intervention, tracked through failures of the real-world or shortfalls as well as successive political loss and financial support toward the next big thing. Even potentially significant interventions often emerge even before sufficient evidence confirms them, with a wave of recent premature enthusiasm as well as accompanying financing which 
efficiently set the platform for failure. While, air pollution naturally disrupts the ordinary business and pleasure of life, given reasons enough for the vigour of the complaints nowadays, there remains a big question about the nature of air pollution that people breathe around sawmills as well as several glitches that its pollution could cause on public health (increase of infections, respiratory, pulmonary as well as cardiovascular diseases) and on the milieu (global warming, ozone layer destruction, climatic catastrophes). It can be concluded that the average concentrations of $\mathrm{CO}, \mathrm{O}_{2}$ as well as other measured parameters like Formaldehyde ( $\mathrm{HcHo})$ etc are mostly lower as well as within acceptable local and global regulatory standards for air quality indices. However, there were few exceptions like the mean concentrations of $\mathrm{PM}_{2.5}, \mathrm{PM}_{10}$, volatile organic compounds (VOCs) as well as Combustible (LEL) respectively higher when compared to local and global standards. This high level of value is due to the high volume of pollutant existing in the sawmill air is due to the input of influents from the activities of the sawmill. As a result, air pollution in Ilorin metropolis and its environs were however, found to be relatively polluted. Therefore, it can be said that radical efforts are essential toward reducing the levels of air pollution around the sawmill milieu. Reducing air pollution preserves as well as improves lives quality. It can help reduce the risk of acute as well as chronic respiratory infections like pneumonia and asthma amongst sensitive as well as vulnerable groups like children. Air pollution reduction will reduce pregnancy complications as well as childbirth for the resident of the sawmill communities, while improving and promoting community development, while, helping individuals to live longer as well as live more productive and benefit from sustainable development as well as climate change mitigation. There is a lack of precise information and data on the diverse pollution sources, the pollution state as well as the degree at sawmills, through the government or municipal authorities and decision makers, which would be an enabler for them to make limit toward air pollution commitments in the country and made the pollution phenomenon from persisting while encouraging man power training that would utilise pollution control approaches to study the distribution, determinants and deterrents of health-related events as a means to their prevention and control.

\section{Recommendations}

Tens of thousands of people, living within the sawmill environment are exposed to toxic chemicals at rates that are among the highest in Nigeria. The exposure level will almost certainly increase dramatically over the next few years, as a multibillion-dollar boom tends to expand the sawmill plants, several in the same communities will face the greatest health risks. Thus, the threat of exposure to noxious chemicals in the air is nothing novel as well as the problem was remarkably worse in communities in the state's sawmill corridor which may perhaps already face severely elevated cancer risks from activity of sawmill. Hence, "The community deserves to know about the risks, and to be heard," "I'm not sure they know about the costs of sawmill activities to our health, to the milieu, to our nature as well as to our quality of life." While, politically contrasting the acceptance for action with scientific uncertainty in terms of risks as well as benefits. It will be reasoned that a more stable research program is required toward getting the right facts around hazardous air pollutants, as well as research toward meeting legal requirements, toward decreasing risk assessment uncertainties, as well as toward addressing and resolving strategic issues. Hence, systems science methods provide remarkable as well as environmental health underexploited tools, particularly in multifaceted milieus that change over time. We work in an unprecedented time of swift innovation as well as with the public health policy team that will progressively search for evidence toward supporting decision-making. Both environmental health observational as well as experimental studies can produce 
big data systems that could be used as both a priori as well as a post hoc system. This information/data sets are generally accumulated through extended, multiyear hard work, frequently with high costs collection. Yet, part of the agency's enforcement problems could be traced toward reduction in the number of employees, frequent staff turnover, employees' high workloads and ineffective data systems". Hence, this research is the first of its kind to take direct measurements of the pollutant plume at monitoring natural attenuation as well as an important vital tool that contributes toward concentration of pollutants monitoring and providing solutions toward tackling air pollution related problems, namely environmental pollution. However, features affecting health could be at the national, neighbourhood, community, or even individual level. Accordingly, research methods, and intervention strategies, vary across the spectrum from individual toward organizational national levels toward improving on the existing air quality monitoring as well as assessment programmes in sawmill environment. Recommendations are made with consideration to the numerous interaction levels to embark on the following:

\subsection{Enhanced monitoring and modelling of air quality at sawmill}

Environmental levels of pollutant can differ vertically as well as horizontally, especially when it comes to saw mill settings. Combined with the need toward identifying actual concentrations of pollutant as well as environmental exposures threats coming out of saw mill environments, information access to residents of predominantly poor communities, researchers, as well as policy makers needs to be ensured thereby showing how emissions of cancer-causing chemicals from clusters of large sawmill facilities will increase overall air toxicity. Correspondingly as significant as the data types collected from the locations aimed at monitoring saw mill pollution. Existing monitoring sites are not always available toward revealing saw mill inequities. Confirmation for the most significant part, there exist insufficient spatial as well as time-based detail toward answering exposure questions related to saw mill environments. Existing monitoring locations might or may not consist of hot spots as well as epitomise the exposure entire area. Dispersion modelling could be used to recognize uptick monitors that could best be located, but adequate monitoring is necessary to ensure that high concentration areas are of high concern. Hot spots are dangerous pollutants that are linked to a high potential for cancer risks or high respiratory illness hazards as well as cancer alley zone that are at present defined by air quality data alone which have fallen dangerously behind. The nature of air pollution monitors ought to consist of site selection based on health hot spots as well as facilities proximity to services and intersections of apprehensions that may increase exposure risk. The growth as well as better targeting practices of prevailing air-monitoring systems will entail a concerted collaboration and effective enforcement effort of local, state, as well as federal agencies, including academia participation as well as community interests to swift and predictable responses.

\subsection{Exposure targeted assessment}

A wide-ranging description of the genuine urban population's exposures could significantly increase the likelihood toward characterizing the risks of ambient concentrations. For example, the continued use as well as more development of passive dosimeters would offer a non-invasive means of monitoring VOC as well as other HAP exposures activities that is both easy as well as practical. For ease of use, these passive monitors are an outstanding instrument aimed at directing community's involvement toward monitoring the ambient concentrations as well as personal exposures. In addition to a detailed description of saw mill exposures, further research are required on the subsequent components of exposure assessment in saw mill settings: Patterns of time - activity in specific community settings, microscale disparities in the ambient concentrations of HAPs as they 
relate toward local sources, research are required on vertical and horizontal gradients in concentrations over trivial spatial scales, better emissions of air quality inventories from nearby sawmill facilities are linked to a high potential for cancer risks or high respiratory illness hazards, toward including both emissions factors and location information, or methods for better stipulating locations in the case of slight dispersed sources, models as well as techniques aimed at making good usage of community-based inventory source data sets to be developed.

\subsection{Interdisciplinary approach to the adoption of data collection and analysis}

Current sources of data from other sectors may be used toward learning more about health differences among sawmill populations. Many of the key data potential valuable sources of data are available for secondary use from record due to administrative systems, such as hospital admissions, vital events registries, may perhaps improve urban health inequities understanding. An interdisciplinary method is also required toward the analyses of the data availability. Health departments ought to play an active and central role in the analysis and use of air quality information, and there ought to be air quality local annual reports, with meetings publicly coordinated through a suitable environmental and health agency. Community environmental health advisory boards must remain established, trained and educated toward interacting with communities particularly resident of sawmill and toward guiding this ongoing effort. Air pollution data collection could be made to be more informative by an approach that is interdisciplinary. One instance is the expanding use of artificial intelligence such as geographic information systems technology and remote sensing in air-monitoring databases construction. Information on the levels of air pollutant as well as the traffic patterns may be overlaid with data on other risk aspects like specific sources of pollution, poverty and crowding. Pollution existing models could be prolonged toward incorporating the biopsychosocial model "(characterizes the nested, interactive ecology of biology, mental function, and social status and relations in a range of human pathologies)" through including derived indices from the various available administrative data sets from agencies of government, using the existing standard tools from population as well as community ecology. These range of data census from housing inspection information, and other emergency services:

1. Raising awareness on the harmful pollutants on communities and residents of the sawmill on vulnerable and sensitive groups like children, pregnant women and the elderly.

2. Develop mechanisms of monitoring, regulations as well as enforcement/mandatory measures and develop goals for how long it ought to take toward issuing enforcement actions as well as tracking their progress.

3. Institute planning policies toward minimizing pollution that might be triggered through future development. Agencies of government like the Kwara State Ministry of Environment ought to join forces with other local and multinationals companies as well as stakeholders in the management of air pollution toward coming up with a wide-ranging air quality management (AQM) scheme for North- Central region of Nigeria.

4. State as well as local government must aggressively broadcast health warning to the resident of the sawmill and its surrounding communities so that they can better improved and protect themselves from polluted air that is considered a major health threat to the environment. 


\section{Conflict of Interests}

The authors affirm that we have no conflict of interest that may be alleged as prejudicing the impartiality of the study reported. This researcher did not receive special assistance from government, not-for-profit sectors or commercial institutions.

\section{Funding}

No specific grant was received for this study.

\section{Consent}

All the authors announced that they had received written notice from the participants.

\section{Disclosure Statement}

The authors are not aware of any biases, affiliations, memberships, funding, or financial holdings that might be perceived as affecting the objectivity of this review.

\section{References}

[1] Raimi Morufu Olalekan, Adio Zulkarnaini Olalekan, Odipe Oluwaseun Emmanuel, Timothy Kayode Samson, Ajayi Bankole Sunday \& Ogunleye Temitope Jide (2020) Impact of Sawmill Industry on Ambient Air Quality: A Case Study of Ilorin Metropolis, Kwara State, Nigeria. Energy and Earth Science Vol. 3, No. 1, 2020. URL: http://dx.doi.org/10.22158/ees.v3n1p1. www.scholink.org/ojs/index.php/ees ISSN 2578-1359 (Print) ISSN 2578-1367 (Online).

[2] Olalekan RM, Timothy AA, Enabulele Chris E, Olalekan AS (2018). Assessment of Air Quality Indices and its Health Impacts in Ilorin Metropolis, Kwara State, Nigeria. Science Park Journals of Scientific Research and Impact 4(4):060-074.

[3] Raimi Morufu Olalekan (2019) 21st Century Emerging Issues in Pollution Control. $6^{\text {th }}$ Global Summit and Expo on Pollution Control May 06-07, 2019 Amsterdam, Netherlands.

[4] Adeolu T, Odipe O. E. and Raimi M. O. (2018). Practices and Knowledge of Household Residents to Lead Exposure in Indoor Environment in Ibadan, Oyo State, Nigeria. Journal of Scientific Research \& Reports 19(6): 1-10, 2018; Article NO. JSRR.43133 ISSN: 2320-0227.

[5] Ruckerl R, Schneider A, Breitner S, Cyrys J, Peters A (2011). Health effects of particulate air pollution: a review of epidemiological evidence. Inhalation toxicology 23(10):555-592.

[6] Héroux ME, Anderson HR, Atkinson R, Brunekreef B, Cohen A, Forastiere F, Künzli N (2015) Quantifying the health impacts of ambient air pollutants: recommendations of a WHO/Europe project. International journal of public health 60(5):619-627.

[7] Raimi Morufu Olalekan, Bilewu Olaolu Oyinlola, Adio Zulkarnaini Olalekan, Abdulrahman Halimat (2019) Women Contributions to Sustainable Environments in Nigeria. Journal of Scientific Research in Allied Sciences. 5(4), 35-51. ISSN NO. 2455-5800. DOI No. 10.26838/JUSRES.2019.5.4.104.

[8] Williams EA, Raimi M, Yarwamara EI, Modupe O (2019) Renewable Energy Sources for the Present and Future: An Alternative Power Supply for Nigeria. Energy and Earth Science 2(2).

[9] Ajayi Folajimi Ajibola, Raimi Morufu Olalekan, Steve-Awogbami Oluseyi Catherine, Adeniji Anthony Olusola, Adebayo Patrick Adekunle (2020) Policy Responses to Addressing the Issues of Environmental Health Impacts of Charcoal Factory in Nigeria: Necessity Today; Essentiality Tomorrow. Communication, Society and Media. Vol 3 , No $3 . \quad$ DOI: https://doi.org/10.22158/csm.v3n3p1. http://www.scholink.org/ojs/index.php/csm/article/view/2940.

[10] Okoyen E, Raimi M O, Omidiji A O, Ebuete A W (2020). Governing the Environmental Impact of Dredging: Consequences for Marine Biodiversity in the Niger Delta Region of Nigeria. Insights Mining Science and technology 2020; 2(3): 555586. DOI:10.19080/IMST.2020.02.555586.https://juniperpublishers.com/imst/pdf/IMST.MS.ID.555586.pdf.

[11] Raimi Morufu Olalekan \& Raimi Aziba-anyam Gift (2020). The Toughest Triage in Decision Impacts: Rethinking Scientific Evidence for Environmental and Human Health Action in the Times of Concomitant Global Crises. CPQ Medicine, 11(1), 01-05.

[12] Raimi Morufu Olalekan, Moses Tuebi, Okoyen Ebikapaye, Sawyerr Henry Olawale, Joseph Beatrice Oka, Oyinlola Bilewu Olaolu (2020) "A Beacon for Dark Times: Rethinking Scientific Evidence for Environmental and Public Health Action in the Coronavirus Diseases 2019 Era" Medical and Research Microbiology, Vol. 1, Issues 3.

[13] Kaufman JD, Elkind MSV, Bhatnagar A, Koehler K, Balmes JR, Sidney S, et al. (2020). Guidance to reduce the cardiovascular burden of ambient air pollutants: a policy statement from the American Heart Association. Circulation. Preprint posted online 5 November 2020, PMID: 33147996, https://doi.org/10.1161/CIR. 0000000000000930.

[14] Chen J, Hoek G. (2020). Long-term exposure to PM and all-cause and cause specific mortality: a systematic review and metaanalysis. Environ Int. Preprint posted online 20 July 2020, PMID: 32703584, https://doi.org/10.1016/j.envint. 2020.105974.

[15] Huang S, Zhang X, Huang J, Lu X, Liu F, Gu D. (2020). Ambient air pollution and body weight status in adults: a systematic review and meta-analysis. Environ Pollut 265(pt A):114999, PMID: 32806418, https://doi.org/10.1016/j.envpol.2020. 114999. 
[16] Yang BY, Fan S, Thiering E, Seissler J, Nowak D, Dong GH, et al. (2020). Ambient air pollution and diabetes: a systematic review and meta-analysis. Environ Res 180:108817, PMID: 31627156, https://doi.org/10.1016/j.envres. 2019.10881.

[17] Morufu Olalekan Raimi, Aziba-anyam Gift Raimi, Teddy Charles Adias (2021). Evidence-based Environmental and Public Health Practices to Respond to the COVID-19 Crisis, 07 May 2021, PREPRINT (Version 1) available at Research Square [https://doi.org/10.21203/rs.3.rs-504983/v1] https://europepmc.org/article/PPRID/PPR335534; EMSID:EMS123969.

[18] Raimi Morufu Olalekan, Emeka Chisom Lucky, Ebikapaye Okoyen, Angalabiri Clement, Christopher Ogbointuwe, Atoyebi Babatunde (2021) COVID-19 Decision Impacts: Vaccine Hesitancy, its Barriers and Impact Studies: Taking Bayelsa State as an Example., 27 May 2021, PREPRINT (Version 1) available at Research Square [https://doi.org/10.21203/rs.3.rs-566532/v1]

[19] Wilson R, Spengler JD (1996). Particles in our air: concentrations and health effects. Boston, MA: Harvard University Press.

[20] World Health Organization (WHO) (2006) Air quality guidelines for particulate matter, ozone, nitrogen dioxide and sulfur dioxide: global update 2005: summary of risk assessment. Geneva: World Health Organization, 2006.

[21] Raimi M O, Suleiman R M, Odipe O E, Salami J T, Oshatunberu M, et al (2019). Women Role in Environmental Conservation and Development in Nigeria. Ecology \& Conservation Science; 1(2): DOI: 10.19080/ECOA.2019.01.555558. Volume 1 Issue 2 - July 2019. https://juniperpublishers.com/ecoa/pdf/ECOA.MS.ID.555558.pdf.

[22] Daniel DC (1989) Environmental Science: A framework for Decision Making (High school edition) Addison-Wesley Publishing Company.

[23] Bell ML, Zanobetti A, Dominici F (2013). Evidence on vulnerability and susceptibility to health risks associated with short-term exposure to particulate matter: a systematic review and meta-analysis. American journal of epidemiology 178(6):865-876.

[24] Rockström J, Steffen W, Noone K, Persson Å, Chapin FS, Lambin EF, Nykvist B (2009). A safe operating space for humanity. nature 461(7263):472-475.

[25] Olalekan RM, Adedoyin OO, Ayibatonbira A, et al (2019). "Digging deeper" evidence on water crisis and its solution in Nigeria for Bayelsa state: a study of current scenario. International Journal of Hydrology. 2019;3(4):244-257. DOI: 10.15406/ijh.2019.03.00187.

[26] Olalekan RM, Omidiji AO, Williams EA, Christianah MB, Modupe O (2019). The roles of all tiers of government and development partners in environmental conservation of natural resource: a case study in Nigeria. MOJ Ecology E Environmental Sciences 2019;4(3):114-121. DOI: 10.15406/mojes.2019.04.00142.

[27] Olalekan R. M, Dodeye E. O, Efegbere H. A, Odipe O. E. Deinkuro N. S, Babatunde A and Ochayi E. O (2020) Leaving No One Behind? Drinking-Water Challenge on the Rise in Niger Delta Region of Nigeria: A Review. Merit Research Journal of Environmental Science and Toxicology (ISSN: 2350-2266) Vol. 6(1): 031-049 DOI: 10.5281/zenodo.3779288.

[28] Olalekan R. M, Vivien O. T, Adedoyin O. O, et al. (2018). The sources of water supply, sanitation facilities and hygiene practices in oil producing communities in central senatorial district of Bayelsa state, Nigeria. MOJ Public Health. 2018;7(6):337-345. DOI: 10.15406/mojph.2018.07.00265.

[29] Isah Hussain Muhammad, Raimi Morufu Olalekan, Sawyerr Henry Olawale, Odipe Oluwaseun Emmanuel, Bashir Bala Getso, Suleiman Haladu (2020) Qualitative Adverse Health Experience Associated with Pesticides Usage among Farmers from Kura, Kano State, Nigeria. Merit Research Journal of Medicine and Medical Sciences (ISSN: 2354-323X) Vol. 8(8) pp. 432-447, August, 2020. DOI: 10.5281/zenodo.4008682. https://meritresearchjournals.org/mms/content/2020/August/Isah\%20et\%20al.htm.

[30] Raimi Morufu Olalekan, Ihuoma Blossom Adindu, Esther Onyinyechi Udensin, Abdulraheem Aishat Funmilayo, Opufou Tarekebi, Deinkuro Nimisingha Sanchez, Adebayo Patrick Adekunle and Adeniji Anthony Olusola (2020) "Health Impact Assessment: Expanding Public Policy Tools for Promoting Sustainable Development Goals (SDGs) in Nigeria". EC Emergency Medicine and Critical Care 4.9 (2020).

[31] Morufu Olalekan Raimi, Tonye Vivien Odubo, Ogah Alima, Henry Akpojubaro Efegbere, Abinotami Williams Ebuete (2021) Articulating the effect of Pesticides Use and Sustainable Development Goals (SDGs): The Science of Improving Lives through Decision Impacts. Research on World Agricultural Economy. Vol 2, No. 1. DOI: http://dx.doi.org/10.36956/rwae.v2i1.347. http://ojs.nassg.org/index.php/rwae/issue/view/31

[32] Raimi MO (2008). The Effect of Vehicular Emission on Human Health. A Case Study of Yenagoa Motor Parks. Unpublished, A Seminar Paper Presented to the Department of Geography and Environmental Management, Niger Delta University, Wilberforce Island, Bayelsa State.

[33] McMichael AJ, Woodward A, Muir C (2017). Climate change and the health of nations: famines, fevers, and the fate of populations. Oxford: Oxford University Press, 2017.

[34] Perera FP (2017). Multiple threats to child health from fossil fuel combustion: impacts of air pollution and climate change. Environmental health perspectives 125(2):141-148.

[35] Johnston FH, Henderson SB, Chen Y, Randerson JT, Marlier M, DeFries, R S, Brauer M (2012) Estimated global mortality attributable to smoke from landscape fires. Environmental health perspectives 120(5):695-701.

[36] Scovronick N, Dora C, Fletcher E, Haines A, Shindell D (2015). Reduce short-lived climate pollutants for multiple benefits. Lancet 386: e28-31.

[37] Raimi Morufu Olalekan, Tonye V. Odubo, Omidiji Adedoyin O, Oluwaseun E. Odipe (2018) Environmental Health and Climate Change in Nigeria. World Congress on Global Warming. Valencia, Spain. December 06-07, 2018.

[38] Morufu Olalekan Raimi, Tonye Vivien Odubo \& Adedoyin Oluwatoyin Omidiji (2021) Creating the Healthiest Nation: Climate Change and Environmental Health Impacts in Nigeria: A Narrative Review. Scholink Sustainability in Environment. ISSN 2470- 
$637 X$ (Print) ISSN 2470-6388 (Online) Vol. 6, No. 1, 2021 www.scholink.org/ojs/index.php/se. URL: http://dx.doi.org/10.22158/se.v6n1p61. http://www.scholink.org/ojs/index.php/se/article/view/3684.

[39] National Academy of Sciences (2010). Hidden costs of energy: unpriced consequences of energy production. Washington, DC: National Academies Press, 2010.

[40] National Academy of Sciences (2012). Exposure science in the 21st century. Washington, DC: National Academies Press, 2012.

[41] Landrigan PJ, Fuller RICHARD (2012). Environmental pollution: an enormous and invisible burden on health systems in lowand middle-income counties. World Hospitals and Health Services 50(4):35.

[42] Epstein PR, Buonocore JJ, Eckerle K, Hendryx M, Stout Iii BM, Heinberg R, Doshi SK (2011). Full cost accounting for the life cycle of coal. Annals of the New York academy of sciences 1219(1):73.

[43] Smith KR, Ezzati M (2005). How environmental health risks change with development: the epidemiologic and environmental risk transitions revisited. Annual Review of Environment and Resources 30:291-333.

[44] Omran AR (2005) The epidemiologic transition: a theory of the epidemiology of population change. The Milbank Quarterly, 83(4):731-757.

[45] Wilkinson P, Smith KR, Beevers S, Tonne C, Oreszczyn T (2007). Energy, energy efficiency, and the built environment. The lancet 370(9593):1175-1187.

[46] Isah, H. M., Sawyerr, H. O., Raimi, M. O., Bashir, B. G., Haladu, S. \& Odipe, O. E. (2020). Assessment of Commonly Used Pesticides and Frequency of Self-Reported Symptoms on Farmers Health in Kura, Kano State, Nigeria. Journal of Education and Learning Management (JELM), HolyKnight, vol. 1, 31-54. doi.org/10.46410/jelm.2020.1.1.05. https://holyknight.co.uk/journals/jelm-articles/.

[47] Olalekan RM, Muhammad IH, Okoronkwo UL, Akopjubaro EH (2020). Assessment of safety practices and farmer's behaviors adopted when handling pesticides in rural Kano state, Nigeria. Arts E Humanities Open Access Journal. 2020;4(5):191-201. DOI: 10.15406/ahoaj.2020.04.00170.

[48] Raimi Morufu Olalekan, Sawyerr Henry Olawale and Isah Hussain Muhammad (2020) Health risk exposure to cypermethrin: A case study of kano state, Nigeria. Journal of Agriculture. 7th International Conference on Public Healthcare and Epidemiology. September 14-15, 2020 I Tokyo, Japan.

[49] Morufu Olalekan Raimi (2021). "Self-reported Symptoms on Farmers Health and Commonly Used Pesticides Related to Exposure in Kura, Kano State, Nigeria". Annals of Community Medicine E Public Health. 1(1): 1002. http://www.remedypublications.com/open-access/self-reported-symptoms-on-farmers-health-and-commonly-used-pesticides-related-6595.pdf. http://www.remedypublications.com/annals-of-community-medicine-public-health-home.php.

[50] Hussain Muhammad Isah, Morufu Olalekan Raimi, Henry Olawale Sawyerr (2021) Probabilistic Assessment of Self-Reported Symptoms on Farmers Health: A Case Study in Kano State for Kura Local Government Area of Nigeria. Research on World Agricultural Economy. Vol 2, No. 1. DOI: http://dx.doi.org/10.36956/rwae.v2i1.336.

[51] Hussain Muhammad Isah, Morufu Olalekan Raimi, Henry Olawale Sawyerr (2021) Patterns of Chemical Pesticide Use and Determinants of Self-Reported Symptoms on Farmers Health: A Case Study in Kano State for Kura Local Government Area of Nigeria. Research on World Agricultural Economy. Vol 2, No. 1. DOI: http://dx.doi.org/10.36956/rwae.v2i1.342. http://ojs.nassg.org/index.php/rwae/issue/view/31

[52] Pope Francis (2015) Laudatosi'. Encyclical letter on care for our common home. Vatican City: The Vatican, 2015.

[53] Whitmee S, Haines A, Beyrer C, Boltz F, Capon AG, de Souza Dias BF, Horton R (2015). Safeguarding human health in the Anthropocene epoch: report of The Rockefeller Foundation-Lancet Commission on planetary health. The Lancet 386(10007):1973-2028.

[54] Raworth K (2017). Doughnut economics: seven ways to think like a 21st-century economist. White River Junction, VT: Chelsea Green Publishing, 2017.

[55] Brauer M, Amann M, Burnett RT, Cohen A, Dentener F, Ezzati M, Van Donkelaar A (2012). Exposure assessment for estimation of the global burden of disease attributable to outdoor air pollution. Environmental science \& technology 46(2):652-660.

[56] Valavanidis A, Fiotakis K, Vlachogianni T (2008). Airborne particulate matter and human health: toxicological assessment and importance of size and composition of particles for oxidative damage and carcinogenic mechanisms. Journal of Environmental Science and Health Part C 26(4):339-362.

[57] Loomis D, Grosse Y, Lauby-Secretan B, El Ghissassi F, Bouvard V, Benbrahim-Tallaa L, Straif K (2013). International Agency for Research on Cancer Monograph Working Group IARC. The carcinogenicity of outdoor air pollution pp. $1262-1263$.

[58] Thurston G, Lippmann M (2015). Ambient particulate matter air pollution and cardiopulmonary diseases. Seminars in Respiratory and Critical Care Medicine 36:422-432.

[59] Lelieveld J, Evans JS, Fnais M, Giannadaki D, Pozzer A (2015). The contribution of outdoor air pollution sources to premature mortality on a global scale. Nature 525(7569):367-371.

[60] Landrigan PJ, Goldman LR (2011). Children's vulnerability to toxic chemicals: a challenge and opportunity to strengthen health and environmental policy. Health Affairs 30(5):842-850.

[61] Grandjean P, Landrigan PJ (2014). Neurobehavioural effects of developmental toxicity. The lancet neurology 13(3):330-338.

[62] Heindel JJ, Balbus J, Birnbaum L, Brune-Drisse MN, Grandjean P, Gray K, Thompson C (2015). Developmental origins of health and disease: integrating environmental influences. Endocrinology 156(10):3416-3421. 
[63] Burnett RT, Pope III CA, Ezzati M, Olives C, Lim SS, Mehta S, Anderson HR (2014). An integrated risk function for estimating the global burden of disease attributable to ambient fine particulate matter exposure. Environmental Health Perspectives 122(4):397-403.

[64] Cohen AJ, Brauer M, Burnett R, Anderson HR, Frostad J, Estep K, Feigin V (2017). Estimates and 25-year trends of the global burden of disease attributable to ambient air pollution: an analysis of data from the Global Burden of Diseases Study 2015 . The Lancet 389(10082):1907-1918.

[65] Tawari CC, Abowei JFN (2012). Air pollution in the Niger Delta Area of Nigeria. International Journal of Fisheries and Auatic Sciences 1(2):92-117.

[66] Molles MC (2005). Ecology Concepts and Applications. 3rd Edn., McGraw-Hill Co. Inc, pp. 93-94.

[67] Bronwen M (1999). The Price of Oil and Human Rights Watch. Perception and Reality: Assessing Priorities for Sustainable Development in the Niger River Delta Retrieved October 3, 2011.

[68] WHO (2009) Global health risks: Mortality and burden of diseases attributable to selected major risks. Geneva, World Health Organization. Available online at http:// www.who.int/healthinfo/global_burden_disease/ GlobalHealthRisks_report_full.pdf (Last accessed on 12th September 2014).

[69] Gorai, A.K., Tuluri, F., Tchounwou, P.B. (2014) A GIS Based Approach for Assessing the Association between Air Pollution and Asthma in New York State, USA. International Journal Environmental Research and Public Health 11(5), 4845-4869. doi:10.3390/ijerph 110504845.

[70] Özdilek HG (2006) An analogy on assessment of urban air pollution in Turkey over the turn of the millennium (1992-2001). Environmental monitoring and assessment 122(1-3):203-219.

[71] Peel JL, Tolbert PE, Klein M, Metzger KB, Flanders WD, Todd K (2005) Ambient air pollution and respiratory emergency department visits. Epidemiology 16:164-174.

[72] Hertz-Picciotto I, Baker RJ, Yap PS, Dostál M, Joad JP, Lipsett M, Pinkerton KE (2007). Early childhood lower respiratory illness and air pollution. Environmental health perspectives 115(10):1510-1518. http://www.scienceparkjournals.org/sri/pdf/2018/September/Olalekan_et_al.pdf.

[73] Ritz B, Wilhelm M, Hoggatt KJ, Ghosh JKC (2007). Ambient air pollution and preterm birth in the environment and pregnancy outcomes study at the University of California, Los Angeles. American Journal of Epidemiology 166(9):1045-1052.

[74] Molitor J, Jerrett M, Chang CC, Molitor NT, Gauderman J, Berhane K, Thomas D (2007). Assessing uncertainty in spatial exposure models for air pollution health effects assessment. Environmental health perspectives 115(8):1147-1153.

[75] Jerrett M, Burnett RT, Ma R, Pope III CA, Krewski D, Newbold KB, Thun, M. J. (2005). Spatial analysis of air pollution and mortality in Los Angeles. Epidemiology pp. 727-736.

[76] Camalier L, Cox W, Dolwick P (2007). The effects of meteorology on ozone in urban areas and their use in assessing ozone trends. Atmospheric Environment 41(33):7127-7137.

[77] Olalekan R. M, Oluwatoyin O and Olalekan A (2020) Health Impact Assessment: A tool to Advance the Knowledge of Policy Makers Understand Sustainable Development Goals: A Review. ES Journal of Public Health; 1(1); 1002.https://escientificlibrary.com/public-health/in-press.php.

[78] Olalekan RM, Oluwatoyin OA, Olawale SH, Emmanuel OO, Olalekan AZ (2020) A Critical Review of Health Impact Assessment: Towards Strengthening the Knowledge of Decision Makers Understand Sustainable Development Goals in the Twenty-First Century: Necessity Today; Essentiality Tomorrow. Research and Advances: Environmental Sciences. 2020(1): 72-84. DOI: 10.33513/RAES/2001-13. https:/ospopac.com/journal/environmental-sciences/early-online.

[79] Adedoyin OO, Olalekan RM, Olawale SH, et al (2020). A review of environmental, social and health impact assessment (Eshia) practice in Nigeria: a panacea for sustainable development and decision making. MOJ Public Health. 2020;9(3):81-87. DOI: 10.15406/mojph.2020.09.00328. https://medcraveonline.com/MOJPH/MOJPH-09-00328.pdf.

[80] Omidiji A. O and Raimi M. O (2019) Practitioners Perspective of Environmental, Social and Health Impact Assessment (ESHIA) Practice in Nigeria: A Vital Instrument for Sustainable Development. Paper Presented at the Association for Environmental Impact Assessment of Nigeria (AEIAN) On Impact Assessment: A Tool for Achieving the Sustainable Development Goals in Nigeria, 7th and 8th November, 2019 in University of Port Harcourt. https://aeian.org/wp-content/uploads/2019/08/EIA-Presentations-Portharcourt.pdf.

[81] Raimi M. O, Omidiji A. O, Adio Z. O (2019) Health Impact Assessment: A Tool to Advance the Knowledge of Policy Makers Understand Sustainable Development Goals. Conference paper presented at the: Association for Environmental Impact Assessment of Nigeria (AEIAN) On Impact Assessment: A Tool for Achieving the Sustainable Development Goals in Nigeria, 7th and 8th November, 2019 in University of Port Harcourt. DOI: 10.13140/RG.2.2.35999.51366 https://www.researchgate.net/publication/337146101.

[82] Sorek-Hamer M, Just AC, Kloog I (2016). The Use of Satellite Remote Sensing in Epidemiological Studies. Current opinion in paediatrics 28(2):228. 